\title{
Mechanical weed control in organic winter wheat
}

\author{
Euro Pannacci, Francesco Tei, Marcello Guiducci \\ Department of Agricultural, Food and Environmental Sciences, University of Perugia, Italy
}

\begin{abstract}
Three field experiments were carried out in organic winter wheat in three consecutive years (exp. 1, 2005-06; exp. 2, 200607 ; exp. 3, 2007-08) in central Italy (42 $57^{\prime} \mathrm{N}-12^{\circ} 22^{\prime} \mathrm{E}, 165 \mathrm{~m}$ a.s.1.) in order to evaluate the efficacy against weeds and the effects on winter wheat of two main mechanical weed control strategies: i) spring tine harrowing used at three different application times ( 1 passage at T1, 2 passages at the time T1, 1 passage at $\mathrm{T} 1$ followed by 1 passage at $\mathrm{T} 1+14$ days) in the crop sowed at narrow (traditional) row spacing $(0.15 \mathrm{~m})$; and ii) split-hoeing and finger-weeder, alone and combined at $\mathrm{T} 1$, in the crop sowed at wider row spacing $(0.30 \mathrm{~m})$. At the time $\mathrm{T} 1$ winter wheat was at tillering and weeds were at the cotyledons- 2 true leaves growth stage. The experimental design was a randomized block with four replicates. Six weeks after mechanical treatments, weed ground cover (\%) was rated visually using the Braun-Blanquet coverabundance scale; weeds on three squares $(0.6 \times 0.5 \mathrm{~m}$ each one $)$ per plot were collected, counted, weighed, dried in oven at $105^{\circ} \mathrm{C}$ to determine weed density and weed above-ground dry biomass. At harvest, wheat ears density, grain yield, weight of 1000 seeds and hectolitre weight were recorded. Total weed flora was quite different in the three experiments. The main weed species were:
\end{abstract}

Correspondence: Euro Pannacci, Department of Agricultural, Food and Environmental Sciences, University of Perugia, Borgo XX Giugno 74, 06121 Perugia, Italy.

E-mail: euro.pannacci@unipg.it

Key words: Finger-weeding; Integrated weed management; Mechanical weed control; Split-hoeing; Spring-tine harrowing.

Acknowledgements: this study was supported by the Project: Progetto di ricerca interregionale PRIS2, Programma Sviluppo Rurale Sottoprogramma Innovazione e Ricerca (Legge 23 dicembre 1999, $n$. 499 - Programmi Interregionali III fase) - Azioni di Innovazione e Ricerca a Supporto del Piano Sementiero - Tematica 2 Individuazioni di tecnologie produttive per l'ottenimento di prodotti sementieri destinati all'agricoltura biologica.

Received for publication: 21 December 2016.

Revision received: 3 May 2017.

Accepted for publication: 6 May 2017.

(C) Copyright E. Pannacci et al., 2017

Licensee PAGEPress, Italy

Italian Journal of Agronomy 2017; 12:900

doi:10.4081/ija.2017.900

This article is distributed under the terms of the Creative Commons Attribution Noncommercial License (by-nc 4.0) which permits any noncommercial use, distribution, and reproduction in any medium, provided the original author(s) and source are credited.
Polygonum aviculare L. (exp. 1 and 2), Fallopia convolvulus (L.) Á. Löve (exp. 1 and 3), Stachys annua (L.) L. (exp. 1), Anagallis arvensis L. (exp. 2), Papaver rhoeas L. (exp.3), Veronica hederifolia L. (exp. 3). In the winter wheat sowed at narrow rows, 2 passages with spring-tine harrowing at the same time seems to be the best option in order to reconcile a good efficacy with the feasibility of treatment. In wider rows spacing the best weed control was obtained by split hoeing alone or combined with finger-weeder. The grain yield, on average 10\% higher in narrow rows, the lower costs and the good selectivity of spring-tine harrowing treatments seem to suggest the adoption of narrow rows spacing in wheat in organic and low-input farming systems.

\section{Introduction}

Over the last two decades, the restriction of herbicide uses in EU due to the past pesticide legislation and the most recent EU Regulation (EC) no 1107 and EU Directive 128/EC (European Commission, 2009a), required each member state to become less dependent on herbicides (Hillocks, 2012; Melander et al., 2015). Furthermore, environmental and human health impact of herbicides use and the increased of organic farming were the main factors that stimulated the interest to develop mechanical weed control methods to use alone or with herbicides in integrated weed control strategies (Pannacci and Tei, 2014).

In organic winter wheat the most frequently used direct weed control method is mechanical weed control by spring tine harrowing, that is normally carried out at the early growth stages of the crop, until early tillering (Rasmussen and Svenningsen, 1995; Graziani et al., 2012). Using a spring tine harrow, all the field surface is treated, and the crop plants are exposed to the same treatment as the weed plants, with the risk of crop damage. Therefore, selectivity, which is usually characterised by the relationship between weed control and crop damage, is a key parameter in post-emergence weed harrowing (Rasmussen et al., 2008; RuedaAyala et al., 2011). Because of low selectivity, post-emergence weed harrowing may reduce crop yields, especially if weed competition is low, timing is unfavourable or implement setting is inappropriate (Rasmussen and Nørremark, 2006; Rasmussen et al., 2010). Studies shown that the primary action with post-emergence tine harrowing was burying plants (Kurstjens and Perdok, 2000), even if uprooting has been acknowledged to play a role with weakly anchored plants (Kurstjens and Kropff, 2001). In this context, the recent development of site-specific mechanical weed management strategies offer the opportunity to increase the efficacy against weeds and to improve the selectivity to the crops (Melander et al., 2015; Pannacci et al., 2017). In particular, the recent automated harrowing systems designed to vary in real-time the harrowing intensity, on the basis of crop and weeds detection by sensors, have showed to increase the harrowing efficacy and balance the trade-off between crop damage and weed control (Rueda-Ayala et al., 2013). Indeed, harrowing intensity refers to 
the cultivation aggressiveness of the tines penetrating into the soil surface that can be varied by varying the tine angle relative to a perpendicular axis to the field surface, varying the depth of the implement, varying driving speed or through various consecutive passes on the same day of cultivation (Cirujeda et al., 2003; Rasmussen et al., 2007). All these setting parameters can be manually or automatically adjusted; however, changing the harrowing intensity by varying the tine angle seems the most appropriate way to develop an automated harrowing system (Rueda-Ayala et al., 2015). Among inter-row mechanical weed control methods, hoeing is a highly selective method and its weed efficacy is not greatly affected by soil moisture, soil type or timing (Rasmussen, 2004). Inter-row hoeing can be more effective that harrowing because inter-row weeds can be easily controlled by most inter-row cultivators (Pannacci and Tei, 2014; Melander et al., 2015). In particular, traditional hoe has a wide range of working tools (blade, sweep, duckfoot, etc.) mounted on a rigid or flexible shank and weed control is mainly achieved by cutting, uprooting and burying of plants; while in rotary hoe, grouped working tools (each operating in inter-row space), such as discs and spike wheels, permit a weed control action reached by uprooting and burying (Pannacci et al., 2017). Both traditional and rotary hoe allow a late mechanical weed control when crop plants are well developed (0.4-0.5 m high and before crop canopy closure), with a high working speed (from 4 to $8 \mathrm{~km} \mathrm{~h}^{-1}$ depending on the hoe) that allows a rapid cultivation with a lower time-consuming and costs (depending on hoe width). These hoes are generally used in the field crops with wide rows (from $0.30 \mathrm{~m}$ to $0.75 \mathrm{~m}$ ) (i.e. maize, sunflower, soyabean, etc.) (Pannacci et al., 2017). However, in the crops with an inter-row space of $0.25-0.30 \mathrm{~m}$, a split-hoe can be favourable used in order to obtain a good inter-row weed control against both broadleaves and grasses, also in relatively advanced developmental stages (Pannacci and Tei, 2014). For these reasons, inter-row weed control can be carried out also in winter wheat, but requires a wider row spacing than normal. Wider rows can reduce the yield wheat and to increase weed biomass (Verschwele, 2007), even if, other studies have not found this to happen (Blair et al., 1997). However, few information are available on wheat in order to clarify the advantage to adopt wider rows to increase the efficacy of mechanical weed control with the risks to decrease yield, with respect to the traditional narrow row managed by spring-tine harrowing for weed control. Therefore, the aim of this paper was to evaluate the efficacy against weeds and the effects on winter wheat of two main mechanical weed control strategies: i) spring tine harrowing used at different application times in the crop sowed at narrow (traditional) row spacing $(0.15 \mathrm{~m})$ and ii) split-hoeing and finger-weeder, alone and combined, in the crop sowed at wider row spacing $(0.30 \mathrm{~m})$.

\section{Materials and methods}

Three field experiments were carried out in organic winter wheat in three consecutive years (exp. 1, 2005-06; exp. 2, 2006-07; exp. 3, 2007-08) in central Italy ( $42^{\circ} 57^{\prime} \mathrm{N}-12^{\circ} 22^{\prime} \mathrm{E}, 165 \mathrm{~m}$ a.s.l.) on a clay-loam soil ( $24.8 \%$ sand, $30.4 \%$ clay) with $0.9 \%$ organic C content. The main agronomic practices are shown in Table 1. Nitrogen fertilisation was applied by incorporation of fertiliser ("Super Endurance N 11", organic nitrogen 11\%, mixture of organic fertilisers, Siamer, Milan, Italy) in the soil, in pre-seeding stage. All the experiments were not irrigated and managed under rainfed conditions. Different mechanical weed control methods were compared (Table 2) in a randomised block experimental design with four replicates and plot size of $16.5 \mathrm{~m}^{2}$ (1.5 m width). All mechanical treatments were performed at time $\mathrm{T} 1$ with the winter wheat at tillering and weeds at the cotyledons- 2 true leaves growth stage; $\mathrm{N} 3$ treatment was performed for the second time at $\mathrm{T} 1+14$ days.

Harrowing was carried out with a $1.5 \mathrm{~m}$-wide spring-tine harrow [Type SF-30, Faza, Italy, (http://www.fazasrl.com/en/) equipped with $7 \mathrm{~mm}$-diameter flexible tines] at a cultivation depth of 10-20 $\mathrm{mm}$ and a driving speed of $6 \mathrm{~km} \mathrm{~h}^{-1}$ (Figure 1).

Split-hoeing was performed with a 1.5 m-wide Asperg Gartnereibedarf split-hoe (Asperg, Germany, for more details see Tei et al., 2002; Pannacci and Tei, 2014) at a cultivation depth of $30-40 \mathrm{~mm}$, a driving speed of $3 \mathrm{~km} \mathrm{~h}^{-1}$ and leaving a $100-\mathrm{mm}$

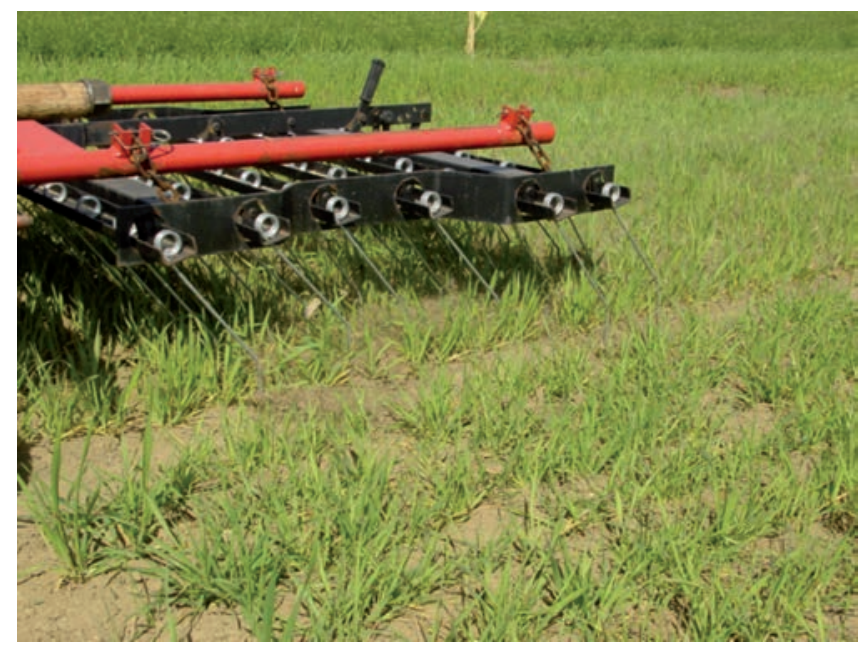

Figure 1. Spring-tine harrowing during the treatment of an experimental plot.

Table 1. Agronomic practices in the field experiments.

\begin{tabular}{|c|c|c|c|}
\hline Experiments and year & Exp. 1 (2005-06) & Exp. 2 (2006-07) & Exp. 3 (2007-08) \\
\hline Preceding crop & Sunflower & Sunflower & Sunflower \\
\hline Sowing date & 21 November 2005 & 15 November 2006 & 09 November 2007 \\
\hline Wheat cultivar & Bilancia & Bilancia & Bilancia \\
\hline Sowing density (viable seeds $\mathrm{m}^{-2}$ ) & 450 & 450 & 450 \\
\hline Fertilisation $\left(\mathrm{kg} \mathrm{ha}^{-1}\right)$ & $100 \mathrm{~N}$ & $100 \mathrm{~N}$ & $100 \mathrm{~N}$ \\
\hline Emergence date & 10 December 2005 & 29 November 2006 & 01 December 2007 \\
\hline Harvest date & 27 July 2006 & 28 June 2007 & 08 July 2008 \\
\hline
\end{tabular}


untilled strip in the crop rows (Figure 2). Split-hoe is an inter-row mechanical mean equipped with goosfoot tine cultivators in front and rotors with steel tine in rear moved by hydraulic power. The goosfoot tine cultivators penetrate and lift the earth, the rotors, turning in the direction of travel between the rows, intercept and crumble the soil and separate (split) earth and weeds. The weeds remain on the soil surface and die quickly. Metal crop shields (100 $\mathrm{mm}$ wide) protect crops from moving soil (Figure 2).

Finger-weeding, an intra-row mechanical control, was carried out with a Kress finger-weeder (Kress Umweltschonende Landtechnik, Germany; http://www.kress-landtechnik.eu/en/ index.php) at a cultivation depth of 20-30 $\mathrm{mm}$ and a driving speed of $3 \mathrm{~km} \mathrm{~h}^{-1}$ (Figure 3). Kress finger-weeder equipments were mounted on Kress Argus System (Kress Umweltschonende Landtechnik, Germany) equipped with special-flat share type Holland (340 mm wide) that works between the rows. Rubber fingers grip from the side around the plant and there they hoe the weeds (Figure 3). In this way, the area, which no other mechanical hoe usually reaches, will be weeded as well. Special-flat share cuts the weeds between the rows that remain on the soil surface and die.

Preliminary tests were carried out in order to set the implements with the aim to obtain a level of cultivation intensity able to guarantee the highest efficacy against the weeds with the lowest crop damage.

Six weeks after mechanical treatments, weed ground cover (\%) was rated visually using the Braun-Blanquet cover-abundance scale (Maarel, 1979). Furthermore, weeds on three squares $(0.6 \times 0.5 \mathrm{~m}$ each one $)$ per plot were collected, counted, weighed, dried in oven at $105^{\circ} \mathrm{C}$ to determine weed density and weed aboveground dry biomass. Weed ground cover was evaluated only in the exp. 1. In the exp. 2 weed ground cover was not adopted due to low infestation level, while weed density and weight were maintained because more appropriated. In the exp. 3 weed density and weight were rated, although weed weight data have not been available due to a technical problem.

At harvest, wheat ears density, grain yield (adjusted to $13 \%$ of moisture content), weight of 1000 seeds and hectolitre weight were recorded. Weight of 1000 seeds was not rated in the exp. 2, due to an omission.

Prior to ANOVA, all data were checked for the assumptions of ANOVA. Data on weed density were square root transformed and data on weed ground cover and weed dry weight were log-transformed (Box and Cox, 1964). All data were subjected to ANOVA and treatment means were separated by Fisher's protected LSD test at $\mathrm{P}=0.05$. A contrast analysis was performed to compare the differences between narrow and wider row factors treatments in a more detailed way. ANOVA and its assumption check was performed with the EXCEL ${ }^{\circledR}$ Add-in macro DSAASTAT (Onofri and Pannacci, 2014).

\section{Meteorological data}

Meteorological data (daily maximum and minimum temperature and rainfall) were collected from a nearby station. Decade averages were calculated and compared with multiannual averages (Figure 4). During the exp. 1 meteorological data showed high rainfalls in the autumn (Oct., Nov. and Dec.) and low in the spring and summer, while temperatures were similar to multiannual average (Figure 4A). During the exp. 2 and exp. 3 rainfalls were lower than in the exp.1, especially in autumn, while temperatures were higher than multiannual averages during the exp. 2 (Figure 4B and C). In particular, total rainfalls during the exp. 1, 2 and 3 were $763 \mathrm{~mm}, 575 \mathrm{~mm}$ and $606 \mathrm{~mm}$, respectively.
Table 2. Mechanical weed control strategies in the field experiments.

Sowing Mechanical weed control methods

Narrow row N1. Spring-tine harrowing (1 passage at the time T1)

spacing N2. Spring-tine harrowing (2 passages at T1)

$(0.15 \mathrm{~m}) \quad$ N3. Spring-tine harrowing (1 passage at T1 +1 passage at T1+14 days) N4. Untreated control

Wider row W1. Split-hoeing (1 passage at the time T1)

spacing W2. Finger-weeding (1 passage at the time T1)

$(0.30 \mathrm{~m}) \quad$ W3. Split-hoeing + Finger-weeding (1 passage at the time T1) W4. Untreated control

$\mathrm{T} 1$, wheat at tillering stage and weeds at cotyledons-2 true leaves stage.

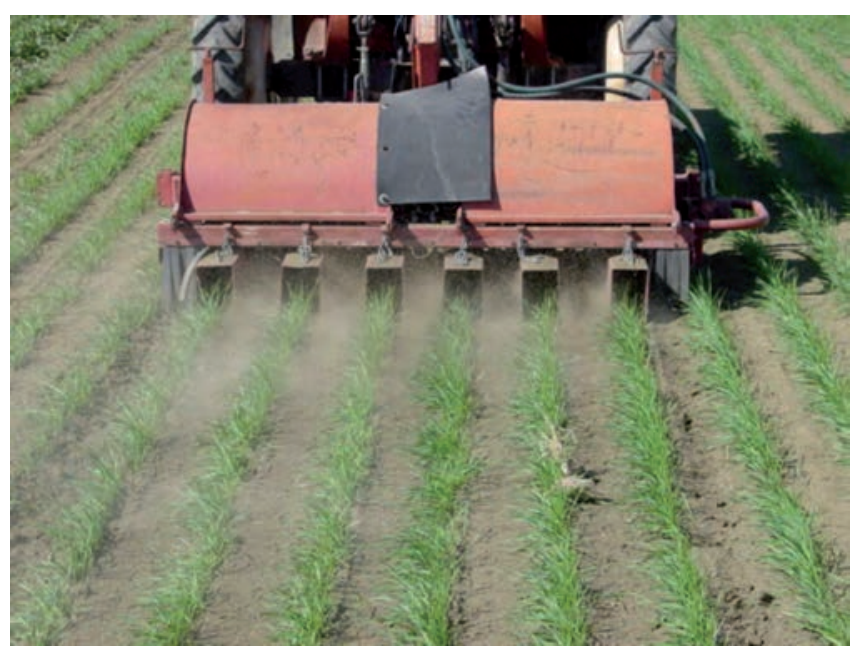

Figure 2. Split-hoeing during the treatment of an experimental plot.

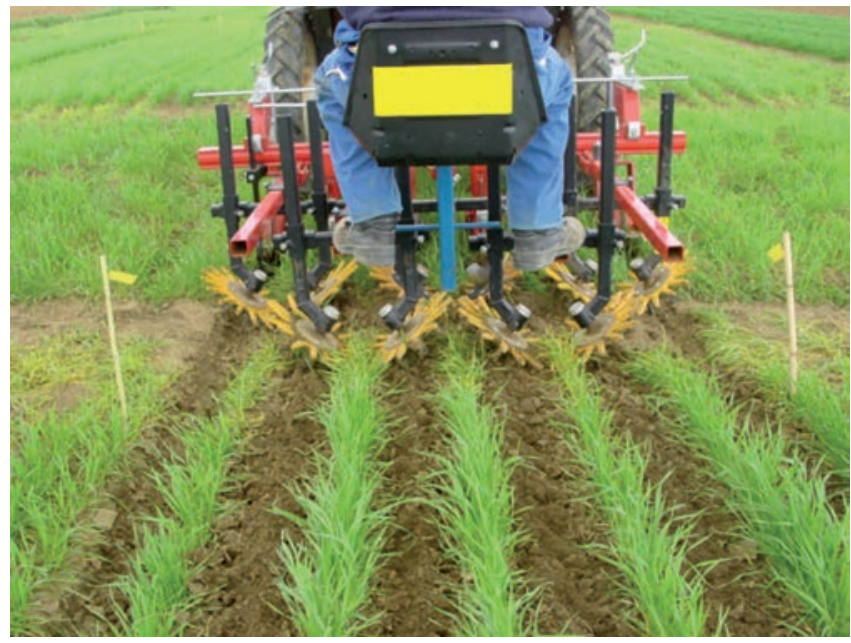

Figure 3. Finger weeding during the treatment of an experimental plot. 


\section{Results and discussion}

The interaction year $x$ treatment was significant for total weed density (14 d.f.; $3.48 F ; 0.0003$ Prob $>F$ ) and total weed dry weight ( 7 d.f.; $2.97 F$; 0.0121 Prob $>F$ ), therefore a separate discussion of each experiment was considered. Total weed flora was quite different in the three experiments. In particular, weeds density on the untreated controls was higher in the exp. 1 (22.7 and 39.3 plants $\mathrm{m}^{-2}$ in N4 and $\mathrm{W} 4$, respectively) (Table 3), the lowest in the exp. 2 (15 and 17.5 plants $\mathrm{m}^{-2}$ in N4 and $\mathrm{W} 4$, respectively) (Table 4), and higher in the exp. 3 (46 and 61.9 plants $\mathrm{m}^{-2}$ in N4 and W4, respectively) (Table 5). The low infestation level in the exp. 2 can be due to the low rainfalls and high temperatures during the two months after sowing (see November and December in Figure 4B), that have reduced weeds emergence, increasing weed seed dormancy. In particular, the main weed species were: Polygonum aviculare L. (exp. 1 and 2), Fallopia convolvulus (L.) Á. Löve (exp. 1 and 3), Stachys annua (L.) L. (exp. 1), Anagallis arvensis L. (exp. 2), Papaver rhoeas L. (exp. 3), Veronica hederifolia L. (exp. 3).

In the exp. 1 total weeds showed significant differences among mechanical treatments (Table 3). In particular, in the winter wheat sowed at narrow row spacing, a double treatment with spring-tine harrowing ( $\mathrm{N} 2$ and N3) was more effective than a single treatment (N1) in reducing density, ground cover and dry weight of the total weeds (Table 3). However, not significant differences were observed between N2 (2 passages at T1) and N3 (1 passage at T1 +1 passage at $\mathrm{T} 1+14$ days) (Table 3 ). These results are in perfect accordance with those of Pardo et al. (2008) that reported as two harrowing passes achieved a higher efficacy than one single pass and little differences were detected if the second pass was conducted the same day, across the sowing direction or 15 days later. Furthermore, Bàrberi et al. (2000) observed that weeds uncontrolled by the first harrowing treatment were not controlled by the second treatment, as they were bigger then. This is because the best efficacy by weed harrowing is generally achieved when weeds are small (Pannacci et al., 2017). For the above mentioned reasons, in wheat at narrow rows, two passes with spring-tine harrowing at the same time seems to be the best option in order to reconcile a good
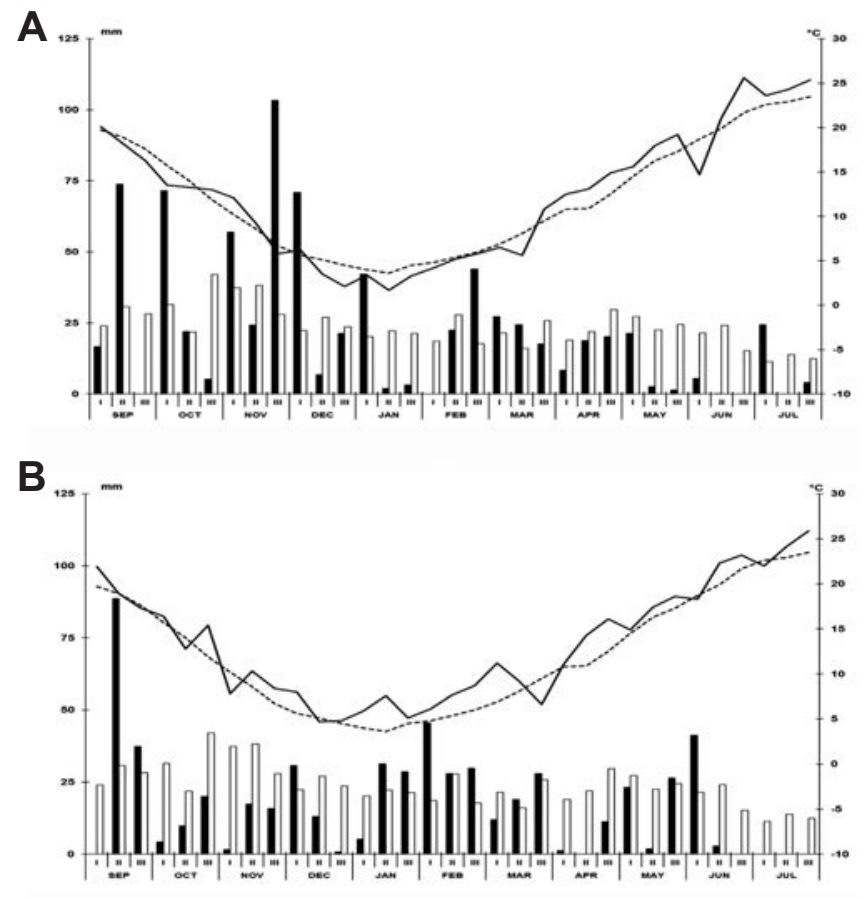

C

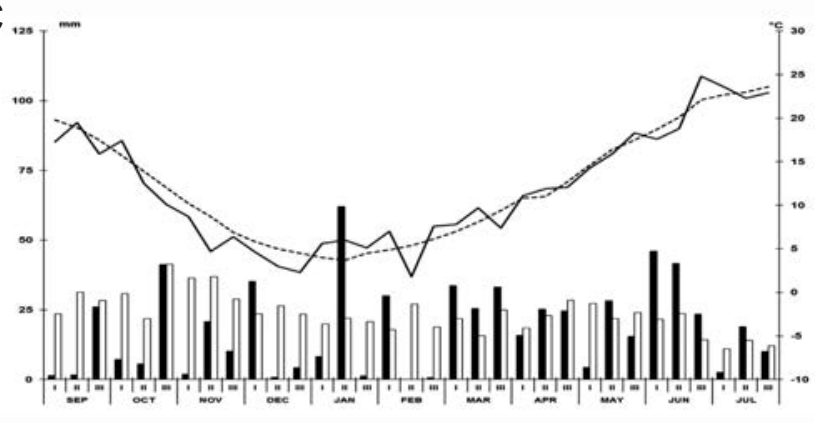

Figure 4. Average decade values of rainfall ( $\mathrm{mm}$; bold bar) and temperature $\left({ }^{\circ} \mathrm{C}\right.$; solid line) recorded during the experiment 1 in 2005-2006 (A), exp. 2 in 2006-2007 (B) and exp. 3 in 20072008 (C), compared to pluriennial (1921-2008) averages (rainfall: mm, empty bar; temperature: ${ }^{\circ} \mathrm{C}$, sketched line).

Table 3. Total weeds and wheat yield parameters recorded in the field experiment 1 (2005-06).

\begin{tabular}{|c|c|c|c|c|c|c|c|c|}
\hline Sowing & $\begin{array}{l}\text { Mechanical } \\
\text { treatments }\end{array}$ & $\begin{array}{l}\text { Ground cover } \\
(\%)\end{array}$ & $\begin{array}{l}\text { lotal weed } \\
\text { Density } \\
\left(n \mathrm{~m}^{-2}\right)\end{array}$ & $\begin{array}{l}\text { Dry weight } \\
\left(g^{-2}\right)\end{array}$ & $\begin{array}{l}\text { Ears density } \\
\qquad\left(\mathrm{n} \mathrm{m}^{-2}\right)\end{array}$ & $\begin{array}{l}\text { Wheat yield pare } \\
\text { Hectolitre weight } \\
\left(\mathrm{kg} \mathrm{hL^{-1 } )}\right.\end{array}$ & $\begin{array}{l}\text { meters } \\
1000 \text { seeds } \\
\text { (g) }\end{array}$ & $\begin{array}{l}\text { Grain yield } \\
\qquad\left(\mathrm{t} \mathrm{ha}^{-1}\right)\end{array}$ \\
\hline \multirow[t]{5}{*}{ Narrow row } & N1 & $22.1^{\mathrm{b}}$ & $19.3^{\mathrm{a}}$ & $5.9^{\mathrm{a}}$ & 510.0 & 84.1 & 37.1 & 5.27 \\
\hline & N2 & $4.0^{c}$ & $6.3^{b}$ & $2.1^{b}$ & 559.2 & 83.8 & 38.1 & 4.93 \\
\hline & N3 & $6.5^{\mathrm{c}}$ & $5.3^{b}$ & $1.2^{\mathrm{b}}$ & 518.3 & 83.9 & 39.1 & 4.92 \\
\hline & $\mathrm{N} 4$ & $41.3^{\mathrm{a}}$ & $22.7^{\mathrm{a}}$ & $7.0^{\mathrm{a}}$ & 486.7 & 84.1 & 38.8 & 5.39 \\
\hline & Significance & $* *$ & $* *$ & $* *$ & ns & ns & ns & ns \\
\hline \multirow[t]{5}{*}{ Wider row } & W1 & $7.3^{b}$ & $10.7^{b}$ & $8.4^{a b}$ & 466.3 & 84.3 & 41.0 & 4.81 \\
\hline & W2 & $5.2^{\mathrm{bc}}$ & $8.7^{b}$ & $2.6^{\mathrm{c}}$ & 485.4 & 84.4 & 39.3 & 4.67 \\
\hline & W3 & $3.3^{\mathrm{c}}$ & $6.3^{b}$ & $4.0^{b c}$ & 413.8 & 84.1 & 39.2 & 4.44 \\
\hline & W4 & $57.3^{\mathrm{a}}$ & $39.3^{\mathrm{a}}$ & $13.8^{a}$ & 445.0 & 84.5 & 39.1 & 4.74 \\
\hline & Significance & $* *$ & $* *$ & $* *$ & ns & ns & ns & ns \\
\hline Narrow row mean & & 18.4 & 13.4 & 4.1 & 518.5 & 84.0 & 38.3 & 5.13 \\
\hline Wider row mean & & 18.3 & 16.3 & 7.2 & 452.6 & 84.3 & 39.6 & 4.67 \\
\hline Narrow row vs wide & row & $\mathrm{ns}$ & ns & ns & $* *$ & $*$ & $*$ & $* *$ \\
\hline
\end{tabular}

N1, spring-tine harrowing (1 passage at the time T1); N2, spring-tine harrowing (2 passages at T1); N3, spring-tine harrowing (1 passage at T1 + 1 passage at T1+14 days); N4, untreated control; W1, split-hoeing (1 passage at the time T1); W2, finger-weeding (1 passage at the time T1); W3, split-hoeing + finger-weeding (1 passage at the time T1); W4, untreated control. a-cIn each column within each sowing type, values followed by the same letter are not significantly different according to the Fisher's protected least significant difference test $(\mathrm{P}=0.05)$, performed on square root transformed data (density) and on log transformed data (ground cover and dry weight). ${ }^{*} \mathrm{P}=0.05 ; * \mathrm{P}=0.01 ; \mathrm{ns}$, not significant. 
efficacy with the feasibility of treatment. In wider row spacing, an effective weed control was obtained by split hoeing and fingerweeder both alone than combined (Table 3). Comparing narrow row $v s$ wider row not significant differences were obtained in terms of total weeds.

Concerning wheat yield parameters, not significant differences were observed among mechanical treatments, while significant differences were obtained comparing narrow row $v s$. wider row (Table 3). In particular, the grain yield was lower in wider rows than in narrow rows, due to a lower ears density, while hectolitre weight and 1000 seeds weight increased in wider row (Table 3).

In the exp. 2 not significant differences were observed among mechanical treatments in terms of total weeds, while the comparison between narrow row $v s$ wider row gave significant effects on the total weeds density and dry weight (Table 4). These results may be due to the low weed infestation that did not allow to emphasise differences on weed control among untreated control and mechanical treatments. Differently, the sowing row spacing seems to be able to affect total weeds in the case of low infestation level, with the narrow rows more effective than wider rows to contain weed density and weight. Indeed, wider rows tend to increase weeds emergence and growth, as already reported by Rasmussen (2004) and Fahad et al. (2015). Wheat yield parameters did not show significant differences in any case, due to the low competition of weeds against wheat (Table 4).

In the exp. 3, total weeds showed significant differences among mechanical treatments, but without significant effects between narrow rows vs. wider rows, confirming what obtained in the exp. 1 (Table 5). In particular, in narrow rows spacing a double treatment with spring-tine harrowing confirm to be more effective

Table 4. Total weeds and wheat yield parameters recorded in the field experiment 2 (2006-07).

\begin{tabular}{|c|c|c|c|c|c|c|}
\hline \multirow[t]{2}{*}{ Sowing } & \multirow[t]{2}{*}{ Mechanical treatments } & \multicolumn{2}{|c|}{ Total weeds } & \multicolumn{3}{|c|}{ Wheat yield parameters } \\
\hline & & $\begin{array}{l}\text { Density } \\
\left(\mathrm{n} \mathrm{m}^{-2}\right)\end{array}$ & $\begin{array}{l}\text { Dry weight } \\
\left(\mathrm{g} \mathrm{m}^{-2}\right)\end{array}$ & $\begin{array}{l}\text { Ears density } \\
\qquad\left(\mathrm{n} \mathrm{m}^{-2}\right)\end{array}$ & $\begin{array}{l}\text { Hectolitre weight } \\
\left(\mathrm{kg} \mathrm{hL}^{-1}\right)\end{array}$ & $\begin{array}{l}\text { Grain yield } \\
\left(\mathrm{t} \mathrm{ha} \mathrm{h}^{-1}\right)\end{array}$ \\
\hline \multirow[t]{5}{*}{ Narrow row } & N1 & 17.1 & 1.1 & 511.7 & 79.1 & 6.60 \\
\hline & $\mathrm{N} 2$ & 5.8 & 0.3 & 446.7 & 79.4 & 6.32 \\
\hline & N3 & 7.1 & 2.3 & 496.7 & 79.7 & 6.56 \\
\hline & N4 & 15.0 & 2.5 & 505.0 & 79.6 & 6.79 \\
\hline & Significance & ns & ns & ns & ns & ns \\
\hline \multirow[t]{5}{*}{ Wider row } & W1 & 8.8 & 4.3 & 473.3 & 79.7 & 6.25 \\
\hline & W2 & 19.2 & 3.4 & 457.9 & 79.2 & 6.30 \\
\hline & W3 & 19.6 & 4.0 & 483.8 & 79.5 & 6.21 \\
\hline & W4 & 17.5 & 4.5 & 472.5 & 79.4 & 6.31 \\
\hline & Significance & ns & ns & ns & ns & ns \\
\hline \multicolumn{2}{|c|}{ Narrow row mean } & 11.3 & 1.5 & 490.0 & 79.4 & 6.57 \\
\hline \multicolumn{2}{|c|}{ Wider row mean } & 16.3 & 4.1 & 471.9 & 79.5 & 6.27 \\
\hline \multicolumn{2}{|c|}{ Narrow row vs wider row } & $*$ & $*$ & ns & ns & ns \\
\hline
\end{tabular}

N1, spring-tine harrowing (1 passage at the time T1); N2, spring-tine harrowing (2 passages at T1); N3, spring-tine harrowing (1 passage at T1 + 1 passage at T1+14 days); N4, untreated control; W1, split-hoeing (1 passage at the time T1); W2, finger-weeding (1 passage at the time T1); W3, split-hoeing + finger-weeding (1 passage at the time T1); W4, untreated control. *P=0.05; ns, not significant.

Table 5. Total weeds and wheat yield parameters recorded in the field experiment 3 (2007-08).

\begin{tabular}{|c|c|c|c|c|c|c|}
\hline Sowing & Mechanical treatments & $\begin{array}{l}\text { Total weeds } \\
\text { Density } \\
\left(\mathrm{n} \mathrm{m}^{-2}\right)\end{array}$ & $\begin{array}{l}\text { Ears density } \\
\qquad\left(\mathrm{n} \mathrm{m}^{-2}\right)\end{array}$ & $\begin{array}{l}\text { Wheat yield part } \\
\text { Hectolitre weight } \\
\left(\mathrm{kg} \mathrm{hL^{-1 } )}\right.\end{array}$ & $\begin{array}{l}1000 \text { seeds } \\
\text { (g) }\end{array}$ & $\begin{array}{l}\text { Grain yield } \\
\left(\mathrm{t} \mathrm{ha}^{-1}\right)\end{array}$ \\
\hline Narrow row & $\begin{array}{l}\text { N1 } \\
\text { N2 } \\
\text { N3 } \\
\text { N4 } \\
\text { Significance }\end{array}$ & $\begin{array}{c}29.7^{\mathrm{ab}} \\
18.2^{\mathrm{b}} \\
20.7^{\mathrm{b}} \\
46.0^{\mathrm{a}} \\
*\end{array}$ & $\begin{array}{c}500.0 \\
534.2 \\
510.0 \\
523.3 \\
\text { ns }\end{array}$ & $\begin{array}{c}80.0 \\
80.1 \\
80.3 \\
80.4 \\
\text { ns }\end{array}$ & $\begin{array}{c}36.5^{\mathrm{b}} \\
38.0^{\mathrm{ab}} \\
38.7^{\mathrm{a}} \\
39.0^{\mathrm{a}} \\
*\end{array}$ & $\begin{array}{c}6.89 \\
6.88 \\
6.67 \\
6.81 \\
\text { ns }\end{array}$ \\
\hline Wider row & $\begin{array}{l}\text { W1 } \\
\text { W2 } \\
\text { W3 } \\
\text { W4 } \\
\text { Significance }\end{array}$ & $\begin{array}{c}10.7^{\mathrm{c}} \\
21.0^{\mathrm{b}} \\
6.0^{\mathrm{d}} \\
61.9^{\mathrm{a}} \\
* *\end{array}$ & $\begin{array}{c}496.3 \\
526.3 \\
500.4 \\
498.3 \\
\text { ns }\end{array}$ & $\begin{array}{l}80.1^{\mathrm{a}} \\
80.2^{\mathrm{a}} \\
79.8^{\mathrm{b}} \\
80.2^{\mathrm{a}} \\
*\end{array}$ & $\begin{array}{c}37.8 \\
38.5 \\
38.3 \\
37.7 \\
\text { ns }\end{array}$ & $\begin{array}{c}6.25 \\
6.56 \\
6.32 \\
6.27 \\
\text { ns }\end{array}$ \\
\hline Narrow row I & & 28.6 & 516.9 & 80.2 & 38.1 & 6.81 \\
\hline Wider row $\mathrm{m}$ & & 24.9 & 505.3 & 80.1 & 38.1 & 6.35 \\
\hline Narrow row $c$ & row & ns & ns & ns & ns & $*$ \\
\hline
\end{tabular}

N1, spring-tine harrowing (1 passage at the time T1); N2, spring-tine harrowing (2 passages at T1); N3, spring-tine harrowing (1 passage at T1 + 1 passage at T1+14 days); N4, untreated control; W1, split-hoeing (1 passage at the time T1); W2, finger-weeding (1 passage at the time T1); W3, split-hoeing + finger-weeding (1 passage at the time T1); W4, untreated control. a-d In each column within each sowing type, values followed by the same letter are not significantly different according to the Fisher's protected least significant difference test $(\mathrm{P}=0.05)$, performed on square root transformed data (density) and on untransformed data (hectolitre weight and 1000 seeds). ${ }^{*} \mathrm{P}=0.05 ; * * \mathrm{P}=0.01 ;$ ns, not significant. 
than a single treatment, while in wider rows spacing the best weed control was obtained by split-hoeing alone (W1) or combined with finger-weeder (W3), as already observed in other crops by Pannacci and Tei (2014). The grain yield was lower in wide rows than in narrow rows, as already obtained in the exp. 1 and mentioned by Champion et al. (1998). Recently, Fahad et al. (2015) confirmed these evidences, finding as lower wheat yields were recorded in wider $(0.23 \mathrm{~m})$ crop rows than that in narrow row spacing $(0.11$ and $0.15 \mathrm{~m})$. In addition, Shapiro and Wortmann (2006) showed as the sowing cereal crops at wider row spacing resulted in increased competition within the crop plant clusters (i.e., the rows), resulting in decreased crop growth and yield compared with narrow row spacing. This seems to suggest the adoption of traditional rows spacing; however, in the cases of high infestation of grass weeds or difficult-to-uproot weeds, the wider rows could offer the opportunity to use inter-row cultivators, like split-hoeing alone or combined with intra-row cultivators, like finger-weeder, more effective than spring-tine harrow. Indeed, Pannacci and Tei (2014), summarising the results of eight field experiments on the mechanical weed control in the same area, showed an average weed control efficacy of $37 \%$ and $73 \%$, for spring-tine harrow and split-hoeing respectively. Furthermore, other authors affirmed that for the inter-row cultivators the trade-off between weed control and crop damage is not significant and weeds are generally well managed by cultivation, while whole-crop cultivators, like springtine harrows show varying and sometimes poor results (Cirujeda and Taberner, 2006; Cloutier et al., 2007; Peruzzi et al., 2007; Van der Weide et al., 2008; Rasmussen et al., 2010). However, it should be point out as by an economical point of view the inter-row cultivators, like split-hoeing or traditional hoeing, seems to be less sustainable than whole-crop cultivators, like spring-tine harrowing. In fact, a spring-tine harrowing treatment costs about $10 € \mathrm{ha}^{-1}$, that means $20 € \mathrm{ha}^{-1}$ in the case of double passes; while a treatment with split-hoeing or traditional hoeing cost about $40 €$ ha $^{-1}$, that can increase of $25 € \mathrm{ha}^{-1}$, adding an intra-row treatment, like finger-weeding (Frondoni, 2003).

Comparing the grain yield among the three experiments, it could be point out the lower values obtained in the exp. 1 with respect to exp. 2 and 3 (Tables 3-5), probably due to the high rainfalls during the autumn occurred in the exp. 1 (Figure 4A), that increased $\mathrm{N}$ leaching during the first phase of wheat growth, causing low levels of available mineral $\mathrm{N}$ in the soil during most of the wheat cycle, as already observed by other authors in the same area (Benincasa et al., 2016; Tosti et al., 2016). Concerning the effects of weed control and crop damage on yield, mechanical treatments did not affect yield although have positively influenced total weeds control. These effects can be explained by a low competition of weeds (prevalence of broad leaves weeds and low or medium infestation levels) and a high competitiveness of wheat, all supported by treatments characterised by a high selectivity with low crop damage. This explanation can be confirmed by Bàrberi et al. (2000) that used eight combinations between four tine adjustments and two treatment intensities (one or two passes), which corresponded to different aggressiveness treatments on durum wheat and did not find significant effects on crop yield. Similar results were also obtained by Dastgheib (2004) using spring-tine harrowing either as single or double passes at 2-3 leaf stage and at 5 leaf stage of organic wheat, finding not significant differences among treatments in terms of grain yield. These experimental evidences confirm the good selectivity of spring-tine harrowing encouraging its application in order to control weeds without wheat yield losses in organic and low input farming systems.

\section{Conclusions}

In organic winter wheat the mechanical weed control seems to be effective either in narrow rows spacing and wider rows spacing. However, in the winter wheat sowed at narrow rows, two passes with spring-tine harrowing at the same time seem to be the best option in order to reconcile a good efficacy with the feasibility of treatment. Indeed, two passes at two different times could not be always practicable, due to adverse weather conditions. The grain yield, on average $10 \%$ higher in narrow rows, the lower costs and the good selectivity of spring-tine harrowing treatments seems to suggest the adoption of narrow rows spacing in wheat in organic and low-input farming systems.

\section{References}

Bàrberi P, Silvestri N, Peruzzi A, Raffaelli M, 2000. Finger-harrowing of durum wheat under different tillage systems. Biol. Agric. Hortic. 17:285-303.

Benincasa P, Farneselli M, Tosti G, Bonciarelli U, Lorenzetti MC, Guiducci M, 2016. Eleven-year results on soft and durum wheat crops grown in an organic and in a conventional low input cropping system. Ital. J. Agron. 11:77-84.

Blair AM, Jones PA, Orson JH, Caseley JC, 1997. Integration of row widths, chemical and mechanical weed control and the effect on winter wheat yield. In: Aspects of applied biology 50, optimising cereal inputs: its scientific basis. Part 2, Crop protection and systems, pp. 385-92.

Box GE, Cox DR, 1964. An analysis of transformations. J. Roy. Stat. Soc. B 26:211-43.

Champion GT, Froud-Williams RJ, Holland JM, 1998. Interactions between wheat (Triticum aestivum L.) cultivar, row spacing and density and the effect on weed suppression and crop yield. Ann. Appl. Biol. 133:443-53.

Cirujeda A, Melander B, Rasmussen K, Rasmussen IA, 2003. Relationship between speed, soil movement into the cereal row and intra-row weed control efficacy by weed harrowing. Weed Res. 43:285-96.

Cirujeda A, Taberner A, 2006. Relating weed size, crop soil cover and soil moisture with weed harrowing efficacy on Papaver rhoeas and other dicotyledoneous weeds in Mediterranean conditions. Biol. Agric. Hortic. 24:181-95.

Cloutier DC, Van Der Weide RY, Peruzzi A, Leblanc M, 2007. Mechanical Weed management. In: M.K. Upadhyaya, R.E. Blackshaw (eds.) Non-chemical weed management: principles, concepts and technology. CABI, Oxon, UK. pp. 111-34.

Dastgheib F, 2004. Optimising tine weeding in organic wheat. N. Z. Plant Prot. 57:41-4.

European Commission, 2009a. Regulation of the European Parliament and of the Council of 21 October 2009 concerning the placing of plant protection products on the market and repealing Council Directives 79/117/EEC and 91/414/EEC, 1107/2009/EC. In: Official Journal, L 309/1, 24.11.2009.

European Commission, 2009b. Directive of the European Parliament and of the Council of 21 October 2009 establishing a framework for Community action to achieve the sustainable use of pesticides, 2009/128/EC. In: Official Journal, L309/71, 24.11.2009.

Fahad S, Hussain S, Chauhan BS, Saud S, Wu C, Hassan S, Tanveer M, Jan A, Huang J, 2015. Weed growth and crop yield 
loss in wheat as influenced by row spacing and weed emergence times. Crop Prot. 71:101-8.

Frondoni U, 2003. Soluzioni meccaniche per un'agricoltura a basso impatto ambientale. Il Divulgatore 10:32-47.

Graziani F, Onofri A, Pannacci E, Tei F, Guiducci M, 2012. Size and composition of weed seedbank in long-term organic and conventional low-input cropping systems. Eur. J. Agron. 39:52-61.

Hillocks RJ, 2012. Farming with fewer pesticides: EU pesticide review and resulting challenges for UK agriculture. Crop Prot. 31:85-93.

Kurstjens DAG, Kropff MJ, 2001. The impact of uprooting and soil-covering on the effectiveness of weed harrowing. Weed Res. 41:211-28.

Kurstjens DAG, Perdok UD, 2000. The selective soil covering mechanism of weed harrows on sandy soil. Soil Tillage Res. 55:193-206.

Maarel E van der, 1979. Transformation of cover-abundance values in phytosociology and its effects on community similarity. Vegetatio 39:97-114.

Melander B, Lattanzi B, Pannacci E, 2015. Intelligent versus nonintelligent mechanical intra-row weed control in transplanted onion and cabbage. Crop Prot. 72:1-8.

Onofri A, Pannacci E, 2014. Spreadsheet tools for biometry classes in crop science programmes. Commun. Biom. Crop Sci. 9:3-13.

Pannacci E, Lattanzi B, Tei F, 2017. Non-chemical weed management strategies in minor crops: A review. Crop Prot. 96:44-58.

Pannacci E, Tei F, 2014. Effects of mechanical and chemical methods on weed control, weed seed rain and crop yield in maize, sunflower and soyabean. Crop Prot. 64:51-9.

Pardo G, Cirujeda A, Aibar J, Cavero J, Zaragoza C, 2008. Weed harrowing in winter cereal under semi-arid conditions. Span. J. Agric. Res. 6:661-70.

Peruzzi A, Ginanni M, Fontanelli M, Raffaelli M, 2007. Innovative strategies for on-farm weed management in organic carrot. Renew. Agr. Food. Syst. 22:246-59.

Rasmussen IA, 2004. The effect of sowing date, stale seedbed, row width and mechanical weed control on weeds and yields of organic winter wheat. Weed Res. 44:12-20.

Rasmussen J, Bibby BM, Schou AP, 2008. Investigating the selectivity of weed harrowing with new methods. Weed Res.
48:523-32.

Rasmussen J, Mathiasen H, Bibby BM, 2010. Timing of postemergence weed harrowing. Weed Res. 50:436-46.

Rasmussen J, Nørremark M, 2006. Digital image analysis offers new possibilities in weed harrowing research. Agriculture 93:155-65.

Rasmussen J, Nørremark M, Bibby BM, 2007. Assessment of leaf cover and crop soil cover in weed harrowing research using digital images. Weed Res. 47:299-310.

Rasmussen J, Svenningsen T, 1995. Selective weed harrowing in cereals. Biol. Agric. Hortic. 12:29-46.

Rueda-Ayala VP, Peteinatos G, Gerhards R, Andújar D, 2015. A non-chemical system for online weed control. Sensors 15:7691-707.

Rueda-Ayala VP, Rasmussen J, Gerhards R, Fournaise NE, 2011. The influence of post-emergence weed harrowing on selectivity, crop recovery and crop yield in different growth stages of winter wheat. Weed Res. 51:478-88.

Rueda-Ayala VP, Weis M, Keller M, Andújar D, Gerhards R, 2013. Development and testing of a decision making based method to adjust automatically the harrowing intensity. Sensors 13:6254-71.

Shapiro CA, Wortmann CS, 2006. Corn response to nitrogen rate, row spacing, and plant density in Eastern Nebraska. Agron. J. 98:529-35.

Tei F, Stagnari F, Granier A, 2002. Preliminary results on physical weed control in processing spinach. In: Proceedings 5th EWRS Workshop on Physical Weed Control, Pisa, Italy, 11-13 March 2002, pp. 164-171. Available from: http:// www.ewrs.org/pwc/doc/2002_Pisa.pdf

Tosti G, Farneselli M, Benincasa P, Guiducci M, 2016. Nitrogen fertilization strategies for organic wheat production: Crop yield and nitrate leaching. Agron. J. 108:770-81.

Van der Weide RY, Bleeker PO, Achten VTJM, Lotz LAP, Fogelberg F, Melander B, 2008. Innovation in mechanical weed control in crop rows. Weed Res. 48:215-24.

Verschwele A, 2007. Reducing weed infestation in winter wheat by sowing technique. In: Proceedings of 7th EWRS Workshop on Physical and Cultural Weed Control, Salem, Germany, 11-14 March 2007, pp. 91-6. 